Canadian University Music Review

Revue de musique des universités canadiennes

\title{
The Cult of the Folk: Ideas and Strategies after Ernest Gagnon
}

\section{Gordon E. Smith}

Volume 19, numéro 2, 1999

Canadian Perspectives in Ethnomusicology

Perspectives canadiennes en ethnomusicologie

URI : https://id.erudit.org/iderudit/1014443ar

DOI : https://doi.org/10.7202/1014443ar

Aller au sommaire du numéro

\section{Éditeur(s)}

Canadian University Music Society / Société de musique des universités canadiennes

\section{ISSN}

0710-0353 (imprimé)

2291-2436 (numérique)

Découvrir la revue

Citer cet article

Smith, G. E. (1999). The Cult of the Folk: Ideas and Strategies after Ernest Gagnon. Canadian University Music Review / Revue de musique des universités canadiennes, 19(2), 16-26. https://doi.org/10.7202/1014443ar
Résumé de l'article

In this paper I discuss ideas of collectors (Édouard-Zotique Massicotte and Marius Barbeau) vis-à-vis the song collection of Ernest Gagnon. The Chansons populaires repertoire is viewed in different ways by Gagnon's successors as historically significant and/or insignificant, and/or an exhaustive, representative "canon" of songs. Approaches to fieldwork, transcription, and the "selection" of repertoire in these collectors' works are also studied. The second part of the paper sets up a critical frame of reference for these strategies based on current literature (e.g., Philip Bohlman, Ian MacKay). Within this discussion, Gagnon's nineteenth-century ideology of "le peuple" is considered alongside the preservationist "cult of the folk" inspiration of his successors.
All Rights Reserved ( C Canadian University Music Society / Société de musique des universités canadiennes, 1999
Ce document est protégé par la loi sur le droit d'auteur. L'utilisation des services d'Érudit (y compris la reproduction) est assujettie à sa politique d'utilisation que vous pouvez consulter en ligne.

https://apropos.erudit.org/fr/usagers/politique-dutilisation/ 


\title{
THE CULT OF THE FOLK: COLLECTING STRATEGIES AFTER ERNEST GAGNON
}

\author{
Gordon E. Smith
}

Pervasive in folk music studies from the beginning of the nineteenth century virtually through to the present has been the attempt to define what folk music is. Very briefly, and I have no intention here of reviewing this history or entering any of the definitional debates, folk music was, and for some still is, a Western concept. Its interface in the last twenty or so years with a variety of disciplines, notably certain of the social sciences, and of course, ethnomusicology, has led to an ideological widening out. Nonetheless, resistance to music of non-Western cultures, and a refusal to acknowledge forces and realities of modern society has perpetuated what Philip Bohlman has called "the conservative undertow" of folk music scholarship: "idealizing and revering a community of folk music that was just out of reach and then fretting over the best ways to rescue folk music before it disappeared."1 This perspective is at the basis of this conservatism and its four corresponding ideological stances: collection, classification, revival, and canonization.

In my research on Ernest Gagnon and his Chansons populaires du Canada (Quebec, 1865-67, 1880), I am increasingly struck by two topics: the first is the actual song repertoire in the Chansons populaires (collection and classification to use Bohlman's terms), followed by the dissemination of this repertoire in subsequent collections, performances, and recordings (i.e., revival and canonization). The second topic is how Gagnon's idealized view of "le peuple" resonates with later collectors' ideas. In one interpretation, for example, one could say that Gagnon manipulated his resources in the Chansons populaires, using a certain popular song repertoire as a nationalist metaphor and identifying the French Canadian people as rustic, hardy, God-fearing, and morally superior. In a current context, one could also say that this imperialistic-even racist-approach is not that far removed from the thinking of a number of Gagnon's successors in both the French and English traditions. In this paper I examine the historical framework of the Gagnon repertoire, subsequent responses to Gagnon's work in the writings of later song collectors, and images of the "folk" within the contexts of these collectors' works. Gagnon's ideas about the "people," as he referred to them, serve as a foundation of what can be regarded as the preservationist, elitist "cult of the folk" movement in this century.

1 Philip V. Bohlman, The Study of Folk Music in the Modern World (Bloomington: Indiana University Press, 1988), xix. 
Within an historic context, Gagnon's Chansons populaires du Canada anticipated later developments in folksong scholarship, particularly in his awareness of different purposes and levels of detail in transcription. For example, Gagnon's removal of the appoggiaturas from the first edition, ostensibly to make the songs easier to sing, foreshadowed what Charles Seeger later distinguished as "prescriptive" and "descriptive" transcription; Gagnon also foreshadowed a Bartók-like distinction between two types of rhythm, "poétique" and "prosaïque" or "oratoire," in folksong. ${ }^{2}$ Further, Gagnon anticipated a later trend of separating rural and urban song repertoires with a view to identifying the "authentic" product and establishing hypotheses on issues of origin. And his precise approach to establishing concordances with contemporaneous published sources anticipated the theme of text and tune dissemination which has been the focus of a number of folksong scholars in this century up to and including Bertrand Bronson in the post-World War II period.

\section{The Gagnon Repertoire in Its Historic ConteXt}

Histories and accounts of French Canadian folksong studies usually acknowledge Gagnon as the precursor of Marius Barbeau and the emergence of serious folklore studies in Quebec in the post-World War I period. However, it is important to situate Gagnon's work accurately as both a product of ethnographic work and a songbook to be used for entertainment. Aside from the fact Gagnon collected about one third of the 100 songs in the Chansons populaires in the field, and notated the rest because they were pervasive songs of the day, he was selective in his choice of songs mainly because he was seeking, in his words, "a certain type"-songs which demonstrated modal features, a characteristic he associated with plainchant and homologously with moral virtue. He also appears to have favoured songs with strongly marked, identifiable rhythmic patterns over embellished, melismatic, "parlando rubato" type melodies. It is possible that if Gagnon encountered "irregular melodies" such as those collected by Édouard-Zotique Massicotte and Marius Barbeau fifty years later, he intentionally or inadvertently chose not to include them because of the difficulties they would have posed for transcription (without a recording device, of course). Or, if he encountered them, maybe he did not consider embellishments part of the song melodies. I have already mentioned that Gagnon, probably under pressure from the publisher of the second edition (Robert Morgan) to make the songs easier to sing, removed the appoggiaturas which he had notated in one third of the songs in the first edition-further enhancing the songbook (i.e., performance) aspect of the Chansons populaires.

In addition to the plainchant-folksong argument as a basis for selecting songs for the Chansons populaires, there is contemporaneous evidence that suggests some of the songs in Gagnon's collection were indeed popular songs of the day. In the 1850s and 1860s, there were a number of published and unpublished collections (mainly of song texts) in circulation in Quebec City

2 James Robbins, "Canada," in Ethnomusicology: Historical and Regional Studies, ed. Helen Myers (New York: W. W. Norton, 1992), 67. 
and Montreal, as well as in smaller centres such as Trois-Rivières. I refer to three of them here. The first is Le chansonnier des collèges series of songbooks first published in Quebec in the 1850s and 1860s (these collections were nearly all texts only). As the title indicates these songs were well known in colleges and seminaries, sung for the purpose of "entertainment and perpetuating patriotism" (preface to the 1850 edition). A comparison of the Gagnon repertoire with repertoires found in the Chansonnier des collèges volumes shows at least twenty concordances, most of which are the songs Gagnon describes in his collection as the best known, or the most "popular"-for example, "À la claire fontaine," "À Saint Malo," "Ah! si mon moine voulait danser!," and "En roulant ma boule." Also important is Gagnon's emphasis on the age and often French origin(s) of some of these pieces, for example "Bal chez Boulé." A second collection which contains music is Thomas-Etienne Hamel's Annales musicales du Petit-Cap, a compilation of sheet music and songs sung at the Petit-Cap seminary and clerical retreat during Hamel's tenure there. This large collection of nearly 200 songs contains at least ten of the same songs as Gagnon's collection (including some of the aforementioned titles). A third source (also with music) is the so-called Ermatinger collection of eleven voyageur songs edited and published by Marius Barbeau in $1954 .{ }^{3}$ Notwithstanding the gap in historical and geographic continuity between Gagnon's collection and the Ermatinger collection (Ermatinger collected these songs when he worked for the Hudson's Bay Company in the west in the 1820s), there are varying degrees of textual similarity between four of Ermatinger's songs and a corresponding number of Gagnon's. With regard to the music, there is only one Ermatinger tune, no. 10 ("Mon père a fait bâtir maison"), which resembles one in Gagnon's collection ("Fringue, fringue, sur l'aviron", pp. 62-63).

My point here is that there was a quite sizeable, ubiquitous, documented, and undocumented repertoire of songs (texts and melodies) in circulation in Quebec at the time Gagnon made his collection. The plainchant-folksong argument, which Gagnon (and others, e.g., Blanche Gagnon) maintained as a basis for the selection of the songs in the Chansons populaires, should be considered also within the broader context of contemporaneous popular song of which there was already a printed (mainly textual) tradition. For another example, we know from literary and historical works of the day (by, for example, Hubert LaRue, Philippe Aubert de Gaspé, Joseph Taché, and HenriRaymond Casgrain) that singing was a common entertainment pastime, both in the country and in towns and cities (despite Gagnon's frequent remarks, especially within the context of his plainchant-folksong argument, distinguishing performance by singers from the country and educated ones from the city). Quite often the songs sung in both rural and urban contexts were the same, Gagnon's distinction between the performance of the songs notwithstanding. An important example here is that many of the paddling songs, sung by

3C. Marius Barbeau, "The Ermatinger Collection of Voyageur Songs (ca. 1830)," Journal of American Folklore 67 (1954): 147-61. 
travellers such as the voyageurs, were popularized and performed beyond their functional context. Furthermore, it is significant that they were sometimes documented in written sources, complementing the folk or oral tradition. Indeed, Gagnon published a number of these songs in his Chansons populaires, and was among the first in a long line of collectors and writers to hold up the voyageur repertoire as a significant part of the folk canon in Quebec. An important corollary is that the age of the voyageur declined with the coming of steam travel in the mid-nineteenth century, coinciding with Gagnon's collecting efforts, and, in folkloristics, with what can be regarded as the first serious attempts by Québécois to document their traditions.

My current work on Gagnon includes a critical edition of the Chansons populaires in which I am attempting to trace the Gagnon repertoire in later printed collections. During the process of this research, I am struck by competing responses to Gagnon's collection. In some instances, these responses are direct; that is, they are contained in comments referring to Gagnon's work. Other more complex responses include the reprinting of versions of songs found in Gagnon's work, with or without acknowledgement, or, alternatively, what might be interpreted as an almost deliberate avoidance-almost an aversion - to the Gagnon repertoire by his successors. And, reaction to my own work on Gagnon for the last number of years, work that has included study and research in Quebec, has been similarly varied. To illustrate, I have listed in the appendix (excerpts 1-3) several commentaries on Gagnon's work and the Gagnon repertoire. It is important to clarify the context of these observations: Gagnon's work-and the work of others referred to in the appendix (excerpts 4-6) - has always been regarded with great respect as historically important; the excerpts cited in the appendix are meant, not to detract from this importance, but to elucidate ideas and strategies I am discussing in this paper.

\section{The Gagnon Canon and Later Folksong Scholarship}

There can be no doubt that the Gagnon collection enlarged the circulation of the songs it contained. The large distribution of the 1865 first edition (approximately 2,500 copies) and, more importantly, the more than a dozen reprintings of the 1880 second edition confirm the popularity of Gagnon's work as a songbook in Quebec. ${ }^{4}$ Some later collections confirmed and added to the pervasiveness of the Gagnon repertoire. The fact that Ferdinand-Cléophas Gagnon copied about three quarters of the Gagnon collection with commentary by hand before Robert Morgan published the second edition in 1880, shows F.-C. Gagnon's desire to preserve the song tradition represented in Gagnon's work. Of the fifty or so songs (texts and melodies) published in the Montreal newspaper Le Canard (1896-98), more than half are taken from, or at least are the same as versions contained in, the Gagnon collection. Ernest Myrand's study, Noëls anciens de la Nouvelle France (first edition, Quebec, 1899), was

4 Gordon E. Smith, "The Genesis of Ernest Gagnon's Chansons populaires du Canada," in Taking a Stand: Essays in Honour of John Beckwith, ed. Timothy J. McGee (Toronto: University of Toronto Press, 1995). 
dedicated by the author to Gagnon, and acknowledges Gagnon's work on the cantique, especially Gagnon's arrangements entitled the Cantiques populaires $d u$ Canada français (first published in 1897), and the Cantiques populaires pour la fête de Noël (1909). For many of Gagnon's successors, however, notably Barbeau, the versions of "popular" or "national" songs, some of which are found in the Chansons populaires, were not regarded as authentic folksongs, even though Gagnon's work was regarded as an inspiration, long held to be exhaustive and therefore not followed up (see appendix, excerpts 1-3).

It was precisely many of these songs that became what I am calling the Gagnon "canon," through their above-mentioned reprintings and many arrangements: Paul-Émile Prévost's 1905 Chansons canadiennes and John Murray Gibbon's Canadian Folk Songs Old and New (1927) are examples. In the case of the latter, Gibbon received permission from Beauchemin to reprint songs from Gagnon's collection with English translation and piano accompaniments. If we move further into the area of performance and recording, the legacy of the Gagnon canon continues. Barbeau's efforts to popularize songs, and also to demonstrate their artistic merit and potential for new musical compositions are well known. His "Soirées du bon vieux temps," organized with Massicotte and devoted to the performance of songs, tales, and dances, began in Montreal in 1919 at the Bibliothèque Saint-Sulpice (renamed the Bibliothèque nationale du Québec), and the "Veillées du bon vieux temps," which took place between 1919 and 1941 at the Monument national in Montreal, are examples. And, of course, the 1927 and 1928 festivals of the Canadian Pacific Railway in Quebec City, which Barbeau organized with John Murray Gibbon, resulted in live performances, as well as compositions and arrangements of a variety of traditional music. Songs from the Gagnon collection continued to be sung at the "Soirées et veillées du bon vieux temps" gatherings; indeed, singers such as Charles Marchand and Jacques Labrecque became well known as "folksingers" of pieces from the Gagnon collection.

\section{The CUlt OF THE "FolK"}

The popularity and continued revival of certain songs from the Gagnon repertoire at times ran counter to the academic instincts of Gagnon's folklorist successors. The competing responses to Gagnon's work-on the one hand a tendency to canonize popular, "national" songs from the Chansons populaires, and, on the other, to discount these pieces as "inauthentic," related to the dual purpose of the collection: it is an ethnography and a songbook. Inherent in these responses is the notion of the "folk," a critical point of departure for the work of virtually all of the collectors and scholars in this century. ${ }^{5}$ Édouard-

5 The use of the word "folk" in connection with song collections in English or French did not appear until the first decades of this century; besides Cecil Sharp's book on English folk song, first published in 1907, the 1925 collection by Barbeau and Edward Sapir was probably the first large Canadian collection to have "folk song" in the title. Dave Harker observes in Fakesong: The Manufacture of British Folksong, 1700 to the Present Day (Milton Keynes: Open University Press, 1985), 129, with reference to British and American ballad contexts: “'Popular' and 'folk' music were being used interchangeably and with extreme vagueness, and the 'people' and the 'folk' likewise." Within a 
Zotique Massicotte, Marius Barbeau, Luc Lacourcière, Conrad Laforte, Roger Matton, and Marc Gagné are some of the well-known names in the French tradition. To this list we can add the leading representatives in the English-language tradition: W. Roy MacKenzie, Louise Manny, Kenneth Peacock, Helen Creighton, and Edith Fowke. In varying guises, virtually all of these collectors conceived their informants in idealized ways. One sees in the work of these collectors a frontier between themselves as collectors and preservers, and their consultants who are presented as the bearers of stories and songs characterized by oral transmission, traditionalism, and anonymity. At the same time, there was the belief on the part of the collectors that this lore was not truly the folk's, and it could be saved only if it was transferred to other hands and other, more modern, means of cultural transmission and preservation. In the minds of many collectors, the folk were a disappearing breed living on the edges of civilization; they had to be sought out and persuaded to part with what they knew. Intrinsic to this cult-of-the-folk thinking is the idea of the prolific informantan individual who knows or remembers in some cases "hundreds" of songs. It might appear that Vincent Ferrier de Repentigny (Massicotte), Philéas Bédard (Barbeau), Angelo Dornan and Ben Henneberry (Creighton), or LaRena Clark (Fowke) were treasured facilitators of some of their respective collectors' most prodigious work. From a current perspective, one interpretation is that the discovery of these individuals was as important as the documentation of their respective repertoires (see appendix, excerpts 4 and 5).

The idea of the prolific informant is related to the preservationist belief that such individuals were a dying breed. In his recent book titled The Quest of the Folk: Antimodernism and Cultural Selection in Twentieth-Century Nova Scotia, Ian McKay refers to factors that produced Helen Creighton's particular reading of Lunenburg County in Nova Scotia as a complex form of paternalism (see appendix, excerpt 6). He maintains that Creighton's blindness to certain historical, economic, and racial facts stemmed from her class perspective. (Creighton came from an educated, privileged, and urban background). She believed that there were havens of unspoiled folk in Nova Scotia but that they were fast disappearing - as McKay points out, a useful argument in attempts to pry funds from reluctant benefactors, no doubt, but also a view that conveyed a sincere and apocalyptic perception of cultural decline. "'The time is pressing, because life is changing and the radio is introducing new music into homes which only knew the old'," she wrote to a like-minded Barbeau in 1947. 'If we wish to retain our treasures, we must do so at once, or the opportunity will be gone."'6 Regarding her search for ballads in southwestern Nova Scotia, Creighton told Barbeau that there were "pitifully few songs" (meaning, of

framework of Newfoundland folklore, Neil Rosenberg points out that, in the prolific work of Gerald Doyle, songs are not called "folksong" but rather "Old Time Songs"; see "Folksong in Newfoundland: A Research History," in Ballades et chansons folkloriques (Quebec: Université Laval, CELAT, 1989), 4. In the history of folklore, ambiguities in terminology are part of the discourse of the meanings of "folk music". See also note 9 below.

6Letter cited in Ian McKay, The Quest of the Folk: Antimodernism and Cultural Selection in Twentieth-Century Nova Scotia (Montreal and Kingston: McGill-Queen's University Press, 1994), 105. 
course, what she called "traditional songs"): "Between the old people having passed away, and the radio bringing a new form of entertainment, there is nothing left to get ... Occasionally a singer would be found who can sing a verse or two of a ballad, but a real old timer who can sing from dawn to dark and never repeat could not be found." 7

Marius Barbeau and the French folklore school in Quebec shared Creighton's (and others') belief in the pressing necessity to conduct tireless fieldwork before "it was too late." Barbeau also distinguished between the authentic folk product and that which had been tainted by popular "modern" urban music. In the preface to his 1947 collection, Alouette, he wrote that his efforts to "popularize" the "chanson populaire" had been exploited by people for commercial purposes and he cited the La bonne chanson series as an example of a popular "modern" repertoire mistakenly taken by people to represent the folksong tradition. Incidentally and importantly, some of this "modern" repertoire consisted of adaptations of the Gagnon song collection. Like Creighton, Barbeau draws a line between newly composed popular song, and the rich and old tradition of folksong. Similarly, one of the goals of Félix-Antoine Savard and Luc Lacourcière, founders of the Archives de folklore at Laval University in 1946, was "the preservation and documentation of the rich oral traditions of our country." 8 The perception was that change brought on by modernism and its resultant industrial and technological development would cause the ideological sense of innocence that characterized collectors' invented cult of the folk to decay and disintegrate. The "folk" in this interpretation was an economic underclass, contented, and quaint in the eyes of the urban gaze. ${ }^{9}$

Gagnon's conception of "le peuple" (the word "folk" is never used) was, in some respects similar to that of his successors. A level of "ethnographic authority," to borrow James Clifford's term, frames the distance Gagnon leaves between himself and the people the song collection is about. The dualism of "us" and "them"-needless to say, a persistent issue in ethnomusicology-is evident first in Gagnon's privileged background, which included a multi-faceted formal education in music, literature, and history. As part of a small intelligentsia in Quebec City, Gagnon idealized the chanson populaire as a living artifact of a chosen, uneducated people. A comment in the preface to his collection makes this clear: he describes the notated parts of the Chansons populaires as not his work, but the work of that "elusive composer known as the people," adding the qualification, "people not educated in music." Gagnon's notion of the people was part of a literary and historical movement characterized by a historical and patriotic orientation and a deeply Roman

7 Ibid., 105.

8 Luc Lacourcière, interview by the author, July 1981.

9For other similar (and different) individual, regional constructions of the "folk," compare Edward Ives's work on Larry Gorman: The Man Who Made the Songs (Bloomington: Indiana University Press, 1964) and Joe Scott, the Woodsman-Songmaker (Champaign: University of Illinois Press, 1978), and David Whisnant's study of the folklore of a small Appalachian community in All That Is Native and Fine: The Politics of Culture in an American Region (Chapel Hill: University of North Carolina Press, 1983). 
Catholic spirit. His notion of the people-especially the moral superiority of the people-was a romantic one, inspired by nineteenth-century French writers on music, such as Fétis, and in line with other contemporaries. Marius Barbeau shared Gagnon's educated background and status within political and academic spheres; and Barbeau expanded significantly upon Gagnon's documentation ideas, incorporating into his (Barbeau's) research not just French Canadian folksong, but also First Nations music and traditions. As a "cultural producer" (McKay's term), Barbeau was a determined and prolific collector, classifier, and popularizer of folk traditions.

I suggest, however, that Gagnon's urban gaze vis-à-vis "le peuple" was different relative to that of his followers' urban gaze vis-à-vis the "folk." Taken as a whole, Gagnon's textual commentary on the repertoire is extensive, but only in a couple of places does he refer to the disappearing, unique repertoire of the people. This runs counter to his twentieth-century successors, as well as to his colleagues from France. For Gagnon, it was a given that there was stasis in the repertoire of his song collection, stasis that paralleled the strong and unwavering character of the French Canadian people. A difference between the French (in France) and French Canadian folk song movements in the middle decades of the nineteenth century was that, whereas France emphasized, above all, the collecting (preservation) of the folk song repertoire, in Quebec folk song was regarded as a means of heightening historical and literary self-consciousness. For Gagnon and his contemporaries in the nationalist Québécois movement of the $1860 \mathrm{~s}$, "le peuple" was a generalized concept linked to the idea of nation ("la race"), and the chanson populaire was a compelling mechanism of identity.

From the time it was first published up to the second decade of this century, the decade which saw the first published fieldwork by Barbeau and the publication of Massicotte's fieldwork from the 1890s, Gagnon's Chansons populaires was regarded in Quebec not just as an exhaustive work, but, in the words of the Beauchemin editors, as "a national treasure linking the past to the future." The best-loved songs from the Gagnon collection, as they came be known in Quebec, continued to be adapted and sung by the emerging breed of chansonniers in the 1920s, cultivated initially by Barbeau's efforts to encourage the performance of folk music and to mix popular and art music traditions. In the decades between the two World Wars the chansonniers became distinctive, perpetuating a song tradition that was different in style and orientation from the oral traditions that preoccupied the Québécois folklorists. Although there were spiritual and patriotic links between the motivation of these groups, there appears a vast difference between both the performance and popular reception of the Quebec singer La Bolduc, and of an elderly informant singing song variants into a researcher's tape recorder. Later, from the 1950s forward, the chansonnier movement was part of the so-called Quiet Revolution in Quebec. Some of its best- known performers, Pauline Julien and Gilles Vigneault, for example, have played important artistic and political roles in shaping recent waves of nationalism in Quebec, most notably during the René Lévesque era, 
and most notably absent during the October 1995 referendum in which colonial and paternalistic themes were at the forefront.

We might think, then, of Gagnon's Chansons populaires as both an early song collection based on some of the ethnographic techniques that have come to dominate fieldwork and writing in this century, as well as a songbook that, in certain quite significant respects, marked the beginning of the documentation of a Québécois musical tradition that, like the French language, identifies the Québécois as the distinct people they so strongly strive to be. Resistance to the alleged unsophistication and, quite simply, perceptions of the unimportance of the "popular" rather than "folk" songs contained in the Chansons populaires repertoire (the Gagnon "canon") are linked to an aversion to modernism and change. Issues of collection, classification, revival, and canonization-ideological stances which began with Gagnon, and have characterized the conservatism of the cult of the "folk" in much of this century-are gradually giving way to concerns about the asymmetrical power shifts that are part of the reality of the global, postcolonial, postmodern world. Sites of identity are fluid, whether they are locally, regionally, ethnically, or individually derived. The definitional debates which surrounded folk music for so long seem moot in the contemporary context.

Perhaps the open-endedness of this discussion parallels the creative kinds of juxtapositions of different musics-east/west, art/popular, and traditional/popular to cite the most obvious examples-which are becoming an exciting, dynamic reality of contemporary music making. Indeed, with respect to folk and traditional music, it is difficult to escape the power of popular music and the creative, inventive choices of a number of popular artists. One might well wonder when and if the cult of the "folk" became, or is becoming, the cult of the popular performer. To illustrate from one particularly rich region in the Canadian musical context, Cape Breton fiddlers Ashley MacIsaac and Natalie MacMaster, and the family groups, the Rankins and the Barra MacNeils, are well known for their varied and innovative reinventing of traditional music (cf. the titles and contents of Natalie MacMaster's most recent CDs, No Boundaries, 1996, and My Roots Are Showing, 1997). In one sense, such blendings of different music intensifies the destruction of the cult of the folk, but also, and more importantly, demonstrates the power of change and the richness of human creativity. One might also wonder that if there is still a "folk," maybe that now means all of us. ${ }^{10}$ Considering realities of folk music in the modern world, Bohlman calls for a reformulation of the conservative ideas surrounding folk music, and a rethinking of old "intractable notions of isolation, ruralness, purely oral tradition, and primary function." 11

10Alan Dundes, who came to the same conclusion by means of a different trajectory in his 1978 essay "Who Are the Folk," in Essays in Folkloristics (Meerut: Ved Prakash Vatuk Folklore Institute, 1978); and McKay, who speculates about the value of using such "an ideologically freighted word" [Folk] if "we are all the Folk," and points to research into ideas of cultural change in folkloristics, notably by scholars at Memorial University in Newfoundland in The Quest of the Folk, 135.

11 Bohlman, The Study of Folk Music, 139. 
In his book, Landscape and Memory, Simon Schama writes about alternative "ways of looking" and "rediscovering what we already have" and what "somehow has eluded our recognition and appreciation." Within current contexts of shifting borderlines between musical genres and sites of time, place, and identity, perhaps such rediscovery processes will yield new stories, and "instead of being yet other explanations of what we have lost, they may become explorations of what we may yet find." 12

\section{Appendix}

\section{Massicotte and Barbeau on the Gagnon Repertoire}

The Chansons populaires du Canada is a collection of one hundred melodies and fewer distinct pieces. ${ }^{3}$

\section{Barbeau on the Gagnon Repertoire}

Not many song records antedating 1865 have come down to us, however. At that date, Ernest Gagnon published his Chansons populaires du Canada, a small but valuable collection. The idea then went abroad that his effort, modest though it was, had drained the fount of local tradition. More songs might have been recorded before they had passed away, but modern life had hushed all folk-singers alike. Tale and legend had vanished forever. The impression among the musicians was that our folk-songs, as represented in the Gagnon collection, were very limited in number and of no great musical importance.

The writer [Barbeau] was under this false impression for many years, until some interesting survivals by the roadside piqued his curiosity. A systematic search during the summer months nearly twenty years ago opened wide vistas. There were still good folk-singers, and many of them. They possessed a treasure-house of songs, over a hundred to one singer alone-more than the whole Gagnon set. The tunes were fresh, rhythmic, and spirited, as if they had been sung for the first time. ${ }^{14}$

\section{Barbeau on the Scope of the Gagnon Repertoire}

And two years later [after La Rue], the young musician Ernest Gagnon recently arrived back from France where the folksong movement was in full swing, published his Chansons populaires $d u$ Canada, a volume containing one hundred traditional songs; although he didn't provide enough information about his Canadian sources, most of the songs were known in Quebec [City] and the regions of the Richelieu and Nicolet Rivers, and Trois-Rivières.

After an attempt full of promise like Gagnon's, there was a sense of expectation. Our Québécois traditions were in full flowering. In spite of this, the century finished without any new work in this potentially fertile area. It appeared that Gagnon's little work had exhausted the limits of the Canadian countryside. ${ }^{15}$

\section{Helen Creighton on Angelo Dornan}

This volume might have been called "The Dornan Book of Songs" because the lyrics and melodies of one singer are pre-eminent. Angelo Dornan's story has been dealt with briefly

12Simon Schama, Landscape and Memory (New York: Alfred A. Knopf, 1995), 14.

13 "Chants populaires du Canada," Journal of American Folklore 32 (January-March 1919): 6 (my translation).

14 Folk Songs of Old Quebec (Ottawa: National Museum of Canada, 1935), 1-2.

15Romancero du Canada (Toronto: Macmillan, 1935), 41 (my translation). 
in my Maritime Folk Songs (p. 47). It is the most extraordinary story in my 40 years' experience as a folklorist. ${ }^{{ }^{6}}$

\section{Edith Fowke on LaRena Clark}

LaRena is the most unusual singer I discovered when I was looking for folk songs in Ontario during the 1950s and 1960s. I met her first in November 1961 ... At that time, she sang twenty-eight songs, almost all ones I had not previously collected, and some that I did not recognize at all. We began a correspondence, during which she sent me other songs on tape and lists of many songs she knew. ${ }^{17}$

\section{McKay's Current Perspective on the Prolific Informant}

... the process of appropriation raised some interesting politico-ethical questions. To put it bluntly, who now remembers Benjamin Henneberry? Yet without his prodigious feats of memory and performance, "Creighton's" collection would never have achieved its national fame and fortune. In the emergent folklore of folklore, Henneberry's achievement was minuscule compared with the heroism of the person who "collected" him. His role in the evolving neo-nationalist narrative was that of a static treasure, not that of a living Folk musician. The aura of greatness and achievement attached not to Henneberry but to Creighton alone. ${ }^{18}$

\section{Abstract}

In this paper I discuss ideas of collectors (Édouard-Zotique Massicotte and Marius Barbeau) vis-à-vis the song collection of Ernest Gagnon. The Chansons populaires repertoire is viewed in different ways by Gagnon's successors as historically significant and/or insignificant, and/or an exhaustive, representative "canon" of songs. Approaches to fieldwork, transcription, and the "selection" of repertoire in these collectors' works are also studied. The second part of the paper sets up a critical frame of reference for these strategies based on current literature (e.g., Philip Bohlman, Ian MacKay). Within this discussion, Gagnon's nineteenth-century ideology of "le peuple" is considered alongside the preservationist "cult of the folk" inspiration of his successors.

16 Folk Songs from Southern New Brunswick (Ottawa: Canadian Centre for Folk Life Studies, 1971), 1. 17Edith Fowke, with Jay Rahn, A Family Heritage: The Story and Songs of LaRena Clark (Calgary: University of Calgary Press, 1994), 3.

18 Ian McKay, The Quest of the Folk, 139. 